\title{
Cadmium tolerance of Typha domingensis Pers. (Typhaceae) as related to growth and leaf morphophysiology
}

\author{
J. P. V. Oliveira ${ }^{a}$, M. P. Pereira ${ }^{a}$, V. P. Duarte ${ }^{a}$, F. F.Corrêa ${ }^{a}$, E. M. Castro ${ }^{a}$ and F. J. Pereira ${ }^{b}$ \\ aPrograma de Pós-graduação em Botânica Aplicada, Laboratório de Anatomia Vegetal, Departamento de Biologia, \\ Universidade Federal de Lavras - UFLA, Campus Universitário, s/n, CP 3037, CEP 37200-000, Lavras, MG, Brazil

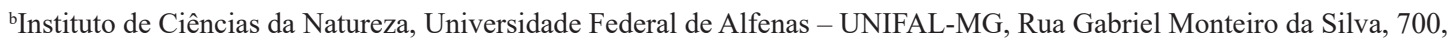 \\ Centro, CEP 37130-001, Alfenas, MG, Brazil \\ *e-mail: fabricio.pereira@unifal-mg.edu.br
}

Received: November 14, 2016 - Accepted: February 7, 2017 - Distributed: October 31, 2018

(With 3 figures)

\begin{abstract}
Typha domingensis (cattail) is a native macrophyte known by its capacity to tolerate several heavy metals effects and the potential use for phytoremediation. However, in despite that cadmium $(\mathrm{Cd})$ is one of the most toxic pollutants; its effects in T. domingensis biology remain uninvestigated. Thus, the objective of this study was to study the tolerance of $T$. domingensis to cadmium contamination by evaluating its growth, $\mathrm{Cd}$ uptake, leaf anatomy and gas exchange. The experiment was designed using three cadmium concentrations $(0,10$ and $50 \mu \mathrm{M})$ and ten replicates for 90 days. The cadmium uptake, growth, gas exchange, chlorophyll content and leaf anatomy were evaluated. Data was submitted to ANOVA and Scott-Knott test for $P<0.05$. Typha domingensis accumulates Cd proportionally to its concentration on the solution and the content of this metal was higher in roots as compared to shoots. Plants showed no significant modifications on growth parameters such as the biomass production, number of leaves, number of clones and the biomass allocation to organs. The photosynthesis, transpiration and chlorophyll content were not modified by Cd. Most anatomical traits evaluated were not modified by the metal but the stomatal density and the proportion of vascular tissues were reduced under $50 \mu \mathrm{M}$ of $\mathrm{Cd}$. In despite, the leaf anatomy showed no toxicity evidences for any Cd level. The absence of growth reduction and the stability of anatomical and physiological traits give insight about the Cd tolerance of this species. Therefore, T. domingensis is able to overcome Cd toxicity and shows potential for phytoremediation.
\end{abstract}

Keywords: aquatic macrophytes, cattail, toxic elements, phytoremediation.

\section{A tolerância ao cádmio por Typha domingensis Pers. (Typhaceae) correlacionada com o crescimento e a morfofisiologia foliar}

\section{Resumo}

A espécie Typha domingensis (taboa) é uma macrófita nativa conhecida por sua tolerância a vários metais pesados e potencial uso na fitorremediação. Contudo, apesar de que o Cd é um dos poluentes mais tóxicos; Seus efeitos em T. domingensis ainda não foram investigados. Assim, o objetivo desse estudo foi avaliar a tolerância de T. domingensis ao cádmio, avaliando o crescimento, absorção de $\mathrm{Cd}$, anatomia foliar e trocas gasosas. $\mathrm{O}$ experimento foi conduzido utilizando três concentrações de $\mathrm{Cd}(0,10$ e $50 \mu \mathrm{M})$ e dez repetições por 90 dias.. O crescimento, trocas gasosas e o teor de clorofila e anatomia foliar foram avaliados. Os dados foram submetidos à ANOVA e ao teste de Scott-Knott para $P<0,05$. A absorção de cádmio, crescimento, trocas gasosas, teor de clorofila e anatomia foliar foram analisados. As plantas de $T$. domingensis podem acumular $\mathrm{Cd}$ proporcionalmente à sua concentração na solução e o teor deste metal foi maior nas raízes em comparação com a parte aérea. As plantas não apresentam modificações significativas nos parâmetros de crescimento como produção de biomassa, número de folhas, número de clones produzidos e alocação de biomassa nos órgãos. A fotossíntese, transpiração e conteúdo de clorofila não foram afetados de forma significativa pelo $\mathrm{Cd}$. A maioria das características anatômicas avaliadas não apresentou diferenças, mas houve redução na densidade estomática e na proporção de tecidos vasculares na concentração de $50 \mu \mathrm{M}$ de Cd. A anatomia foliar não mostrou evidências de toxicidade em nenhum dos níveis de $\mathrm{Cd}$. A ausência de redução de crescimento e estabilidade das características anatômicas e fisiológicas caracteriza alta tolerância da espécie ao Cd. Portanto, T. domingensis é capaz de superar a toxicidade do $\mathrm{Cd}$ e demostra potencial para fitorremediação.

Palavra-chave: macrófitas aquáticas, taboa, elementos tóxicos, fitorremediação. 


\section{Introduction}

It is well known that increased heavy metal deposition in the environment is an emerging problem worldwide. Cadmium $(\mathrm{Cd})$ is one of the most toxic heavy metals for plants and animals (Gratão et al., 2005). Cadmium can be found in soils and wetlands were it becomes available to plants (Souza et al., 2009). This metal is naturally found in soils due to the decomposition of rocks, but its level increases with anthropic activities such as industry and the application of fertilizers in large scale agriculture (Gratão et al., 2005). In Brazil, the Cd level can increase in soils due to the application of phosphate fertilizers (Gonçalves et al., 2008). The critical levels for $\mathrm{Cd}$ toxicity in plants range from $6-10 \mu \mathrm{g} \mathrm{g}^{-1}$ of plant dry mass (Krämer, 2010). Cadmium may cause reduction on growth and poor plant development (Benavides et al., 2005). The lower growth capacity under $\mathrm{Cd}$ contamination is related to lower photosynthesis (Pietrini et al., 2003). However, in tolerant species such as Lonicera japonica (Jia et al., 2015), Schinus molle (Pereira et al., 2016) and Eichhornnia crassipes (Pereira et al., 2017) increased photosynthesis and growth can be found in response to Cd stress.

Tolerant plants are useful for the application on phytoremediation systems that are used to scavenge heavy metals from polluted spots. This method can be efficient to clean contaminated environments at a lower cost (Perkovich et al., 1996) and tolerant macrophytes can be applied to the remediation of wetlands (Pereira et al., 2011, 2014). The Typha domingensis Pers. (cattail) is found in Americas, Europe, Africa and Asia, being worldwide distributed as a native (South America) or invasive macrophyte, but it shows high potential for phytoremediation. Typha domingensis plants are comprised of a shoot constituted only by leaves; underground rhizome which produces adventitious roots, the inflorescence has male and female leaves. The leaves of $T$. domingensis are comprised of one-layered epidermis on both adaxial and abaxial sides, palisade parenchyma (three to four layers) also on both abaxial and adaxial leaf surfaces and the central part shows aerenchyma chambers and collateral vascular bundles (Santos et al., 2015; Corrêa et al., 2016). Typha domingensis modifies its leaf anatomy and photosynthesis in response to environmental conditions such as phosphorus eutrophication (Santos et al., 2015; Corrêa et al., 2016) and population density (Corrêa et al., 2016). This species is tolerant and can accumulate high levels of nickel, zinc (Mufarrege et al., 2014), mercury (Lominchar et al., 2015), and cromium (Mufarrege et al., 2015), however, its tolerance to $\mathrm{Cd}$ remains unclear. In addition, $T$. domingensis has been recently investigated due to its high potential to be applied in phytoremediation systems (Hegazy et al., 2011). Therefore, the study of the Cd tolerance and uptake by T. domingensis may be important to its application on phytoremediation systems.
Thus, this work aimed to evaluate the Cd tolerance of Typha domingensis and the effect of this pollutant on $\mathrm{Cd}$ uptake, plant growth, and leaf anatomy and gas exchange.

\section{Material and Methods}

\subsection{Plant material and experimental design}

The experiment was carried out in a greenhouse located at the Universidade Federal de Lavras (UFLA), state of Minas Gerais, Brazil (2113'17'S and 44'57'47'W). Typha domingensis plants were collected from natural populations in wetlands located at the UFLA campus. The collected plants were comprised of rhizomes (about $20 \mathrm{~cm}$ in length and $2.5 \mathrm{~cm}$ in diameter $)$, roots $(10 \mathrm{~cm}$ in length) and approximately ten leaves (1.5 $\mathrm{m}$ in length). These plants were washed with tap water before further cultivation in the greenhouse. The plants were grown in plastic pots containing $5 \mathrm{~L}$ of nutrient solution (Hoagland and Arnon, 1950) at 40\% of the ionic strength for $90 \mathrm{~d}$ to obtain acclimatized clones. During propagation, the nutrient solution was replaced at $15 \mathrm{~d}$ intervals and the water lost by evapotranspiration refilled daily.

Passed the propagation period, 30 pathogen-free plants were selected according to size (five leaves and $20 \mathrm{~cm}$ in length) to be used in the experiment. Plants were transferred to plastic pots containing nutrient solution at $40 \%$ of ionic strength (Hoagland and Arnon, 1950) using the following salts: $\mathrm{NH}_{4} \mathrm{H}_{2} \mathrm{PO}_{4}, \mathrm{Ca}\left(\mathrm{NO}_{3}\right)_{2}, \mathrm{Mg}\left(\mathrm{NO}_{3}\right)_{2}, \mathrm{KNO}_{3}, \mathrm{~K}_{2} \mathrm{SO}_{4}$, $\mathrm{FeSO}_{4} \cdot 7 \mathrm{H}_{2} \mathrm{O}$,

$\mathrm{H}_{2} \mathrm{BO}_{3}, \mathrm{MnSO}_{4} \cdot \mathrm{H}_{2} \mathrm{O}, \mathrm{ZnSO}_{4} \cdot 7 \mathrm{H}_{2} \mathrm{O}, \mathrm{CuSO}_{4} \cdot 5 \mathrm{H}_{2} \mathrm{O}$, $\mathrm{H}_{2} \mathrm{MoO}_{4} \cdot \mathrm{H}_{2} \mathrm{O}$. This nutrient solution was modified by the addition of $\mathrm{Cd}\left(\mathrm{NO}_{3}\right)_{2}$ at the 0,10 and $50 \mu \mathrm{M}$ concentrations. The Cd levels applied were selected as the control (zero Cd), the Cd concentration that caused no toxicity in Schinus molle $(10 \mu \mathrm{M})$ and the level were $\mathrm{Cd}$ was toxic to these plants $(50 \mu \mathrm{M})$ according to Pereira et al. (2016) the levels of Cd were selected to compare with an tolerant species (Schinus molle) as shown by the authors. The experiment was conduced at greenhouse for $60 \mathrm{~d}$; the experimental design was completely randomized with three treatments (Cd concentrations) and ten replicates. Replicates were constituted of one plant.

\subsection{Cadmium uptake analysis}

At the end of the experiment the $\mathrm{Cd}$ content in plants was measured. Plants were dried at $45^{\circ} \mathrm{C}$ for $72 \mathrm{~h}$. Further, the dried mass $(500 \mathrm{mg})$ was triturated in small particles and then digested in $10 \mathrm{~mL}^{\circ} \mathrm{HNO}_{3}$ for $30 \mathrm{~min}$ at $150{ }^{\circ} \mathrm{C}$ in a block digestion system. Subsequently, $1.0 \mathrm{~mL}$ of $\mathrm{HClO}_{4}$ was added, and the temperature was elevated to $210^{\circ} \mathrm{C}$ for $20 \mathrm{~min}$. The digested material was diluted to a volume $25 \mathrm{~mL}$ with distilled water, and the $\mathrm{Cd}$ content was determined, according to Welz and Sperling (2008) with an atomic absorption spectrometer SpectrAA 220 (Varian Inc., Palo Alto, USA). 


\subsection{Growth analysis}

The number of leaves and new shoots were counted on a daily basis. The length and width of the tallest leaf were measured weekly using a metric ruler. For the number of leaves and leaf length and width data was shown as the final values at the end of the experiment. At the end of the experiment the plants were sampled and separated in leaves, roots and rhizomes. Fresh leaves were scanned and the leaf area was measured in the ImageJ image analysis software according to Pereira et al. (2016).

\subsection{Gas exchange and chlorophyll content analysis}

The chlorophyll content was assessed using a chlorophyll meter SPAD-502 (Konica-Minolta, Japan) in the leaf base, median and apex regions and data was averaged to one leaf. Gas exchange analysis was performed with an infrared gas analyzer (IRGA) model LI-6400XT (Li-COR Biosciences, Lincoln, Nebraska, USA), with a $6 \mathrm{~cm}^{2}$ chamber and the red/blue LED light source (LI-6400-02B, Li-Cor, Lincoln, Nebraska, USA). These evaluations were performed at the median region of pathogen-free leaves developed within experimental period. The measurements were made between 8-11 a.m., and the Photosynthetic Photon Flux density (PPFD) was standardized at $1000 \mu \mathrm{mol} \mathrm{m} \mathrm{m}^{-2} \mathrm{~s}^{-1}$, the vapor pressure deficit was $2.66 \mathrm{kPa}$ and the pump flow was $500 \mu \mathrm{mol} \mathrm{s}^{-1}$. The net photosynthesis (A) and transpiration rate $(\mathrm{E})$ were evaluated in two leaves per replicate and data was averaged to each replicate.

\subsection{Anatomical analysis}

Leaf samples (10 $\mathrm{cm}$ in length) were obtained from the median region and fixed in a solution of F.A.A. $70 \%$ (formaldehyde, acetic acid and 70\% ethanol 1:1:18) for 72 hours and then stored in $70 \%$ ethanol until further analysis (Johansen, 1940). The paradermic sections from both the adaxial and abaxial leaf sides were performed using steel blades and further sections were stained with $0.1 \%$ safranin $\left(\mathrm{m} \mathrm{v}^{-1}\right)$. Transversal sections were obtained with a bench-top microtome and stained with safrablau solution ( $1 \%$ safranin and $0.1 \%$ astra-blau in a ratio of 7:1) according to Kraus and Arduin (1997). Images were obtained with an Olympus CX31 light microscope attached to image capture system (Olympus, Tokyo, Japan). Image analysis was performed using the Image J software in one slide and five fields per replicate. Data was averaged to each replicate.

\subsection{Statistical analysis}

The data were subjected to statistical analysis using SISVAR 5.0 software (Ferreira, 2011). Prior to parametric analysis, the data were tested for a normal distribution using the Shapiro-Wilk test and then to one-way ANOVA and the Scott-Knott test to $P<0.05$. The experiments for the growth analysis, gas exchange, chlorophyll content and anatomical analysis constituted of three treatments (Cd concentrations) and ten replicates of one plant. $\mathrm{The} \mathrm{Cd}$ uptake analysis was performed in factorial $3 \times 2$ scheme (three $\mathrm{Cd}$ levels $\mathrm{x}$ two plant parts) and ten replicates of one plant. Data of different analyses were averaged to the general experimental design (ten replicates of one plant) previously to statistical analysis.

\section{Results}

\subsection{Cadmium uptake}

Typha domingensis showed increased Cd uptake according to higher pollutant levels on the solution. However, the $\mathrm{Cd}$ content was different for roots and shoots. Roots showed increased $\mathrm{Cd}$ content proportionally to the concentration of this metal on the solution whereas the $\mathrm{Cd}$ levels in shoots increased only at the $50 \mu \mathrm{M}$. In addition, Cd content in plants showed no significant differences for the control solution. However, under $\mathrm{Cd}$ contamination, the content of this metal in roots was 150 fold higher as compared to shoots for the plants grown under $10 \mu \mathrm{M}$ and 11 fold for the plants under $50 \mu \mathrm{M}$ (see Table 1).

\subsection{Growth and gas exchange analysis}

The growth parameters of Typha domingensis were not modified by Cd contamination. The number of leaves and new shoots as well as the leaf length and width showed no significant differences in Cd-treated plants. In addition, no Cd effects were found to the plant dry mass or the biomass allocation to roots, rhizomes and leaves (see Table 2). In addition, no modifications were found to the net photosynthesis (A), transpiration (E) or the chlorophyll content in the $\mathrm{Cd}$ treated plants (see Table 3 ).

\subsection{Anatomical analysis}

The stomata of both adaxial and abaxial leaf surfaces of $T$. domingensis showed little modification under $\mathrm{Cd}$ treatments. On the abaxial side, plants under $50 \mu \mathrm{M}$ of $\mathrm{Cd}$ had reduced stomatal density, but no effect was found for the stomatal index (see Table 4). In addition, no Cd effect was found to the stomatal density, whereas the stomatal index was increased by $14.5 \%$ on the leaf adaxial side of the plants exposed to $10 \mu \mathrm{M} \mathrm{Cd}$ (see Table 4). However, no toxicity evidence was promoted by $\mathrm{Cd}$ as stomata from all treatments preserved the overall structure (see Figure 1).

Table 1. Cadmium uptake by Typha domingensis grown under different concentrations of the pollutant. Data is shown as mean \pm standard deviation.

\begin{tabular}{ccc}
\hline Cadmium $(\boldsymbol{\mu M})$ & Roots $(\mathbf{p p m})$ & Shoot $(\mathbf{p p m})$ \\
\hline 0 & $0 \pm 0 \mathrm{cA}$ & $3.35 \pm 3.0 \mathrm{bA}$ \\
10 & $188.62 \pm 11.3 \mathrm{bA}$ & $1.25 \pm 1.7 \mathrm{bB}$ \\
50 & $234.10 \pm 08.1 \mathrm{aA}$ & $21.3 \pm 7.2 \mathrm{aB}$
\end{tabular}

Coefficient of

variation $=8.9 \%$

Means followed by the same uppercase letters in rows or lowercase letters in columns do not differ according to the Scott-Knott test at $P<0.05$. 
The epidermis thickness of the leaves of $T$. domingensis was not modified by the Cd concentrations (see Table 4). However, this pollutant reduced the thickness of the palisade parenchyma on the adaxial side of the leaves (see Table 4 and Figure 2). The overall structure of the epidermis and palisade parenchyma showed no toxicity signs such as deformation or necrosis (see Figure 2). The aerenchyma percentage was not modified by Cd (see Table 4 and Figure 3 ). However, Cd reduced by $21.57 \%$ the proportion of xylem and phloem in the vascular bundles of $T$. domingensis leaves (see Table 4) whereas no effect was found on the xylem vessel diameter (see Table 4).

Table 2. Growth parameters of Typha domingensis grown under cadmium contamination. Data is shown as mean $\pm \operatorname{standard}$ deviation.

\begin{tabular}{ccccc}
\hline Variable & $\mathbf{0} \boldsymbol{\mu M}$ Cadmium & $\mathbf{1 0} \boldsymbol{\mu M}$ Cadmium & $\mathbf{5 0} \boldsymbol{\mu M}$ Cadmium & $\begin{array}{c}\text { Coefficient of } \\
\text { variation \% }\end{array}$ \\
\hline NS & $13 \pm 4 \mathrm{a}$ & $11 \pm 4 \mathrm{a}$ & $9 \pm 3 \mathrm{a}$ & 35.9 \\
$\mathrm{NL}$ & $12 \pm 4 \mathrm{a}$ & $13 \pm 2 \mathrm{a}$ & $12 \pm 2 \mathrm{a}$ & 34.5 \\
LW (cm) & $0.92 \pm 0.2 \mathrm{a}$ & $0.92 \pm 0.3 \mathrm{a}$ & $1.01 \pm 0.13 \mathrm{a}$ & 23.5 \\
LL (cm) & $116.27 \pm 23.04 \mathrm{a}$ & $124.82 \pm 13.87 \mathrm{a}$ & $102.75 \pm 17.43 \mathrm{a}$ & 35.9 \\
$\begin{array}{c}\text { Plant dry mass (g) } \\
\text { Root biomass } \\
\text { allocation (\%) }\end{array}$ & $39.04 \pm 14.8 \mathrm{a}$ & $48.38 \pm 13.9 \mathrm{a}$ & $33.04 \pm 14.70 \mathrm{a}$ & 20.1 \\
$\begin{array}{c}\text { Rhizome biomass } \\
\text { allocation (\%) }\end{array}$ & $17.48 \pm 1.8 \mathrm{a}$ & $16.17 \pm 3.1 \mathrm{a}$ & $20.91 \pm 1.9 \mathrm{a}$ & 12.8 \\
$\begin{array}{c}\text { Leaf biomass } \\
\text { allocation (\%) }\end{array}$ & $78.83 \pm 12.8 \mathrm{a}$ & $77.85 \pm 10.9 \mathrm{a}$ & $72.12 \pm 13.1 \mathrm{a}$ & 16.1 \\
\hline
\end{tabular}

Means followed by the same letters in lines do not differ according to the Scott-Knott test at $P<0.05$. (NS)= number of new shoots per plant; (NL)= number of leaves per plant; (LW)= leaf width; (LL)= leaf length.

Table 3. Gas exchange and chlorophyll content of Typha domingensis leaves developed under Cd contamination. Data is shown as mean \pm standard deviation.

\begin{tabular}{|c|c|c|c|}
\hline Cadmium $(\mu \mathrm{M})$ & $\begin{array}{c}\mathrm{A} \\
\left(\mu \mathrm{mol} \mathrm{CO} \mathrm{Cm}^{-2} \mathrm{~s}^{-1}\right)\end{array}$ & 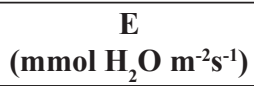 & $\begin{array}{l}\text { Chlorophyll content } \\
\text { (SPAD units) }\end{array}$ \\
\hline 0 & $13.18 \pm 2.70 \mathrm{a}$ & $6.20 \pm 1.60 \mathrm{a}$ & $52.55 \pm 9.50 \mathrm{a}$ \\
\hline 10 & $13.48 \pm 2.68 \mathrm{a}$ & $6.77 \pm 1.50 \mathrm{a}$ & $44.47 \pm 7.10 \mathrm{a}$ \\
\hline 50 & $14.21 \pm 2.50 \mathrm{a}$ & $6.97 \pm 1.20 \mathrm{a}$ & $53.71 \pm 20.80 \mathrm{a}$ \\
\hline Coefficient of variation & $19.9 \%$ & $21.4 \%$ & $39.5 \%$ \\
\hline
\end{tabular}

Means followed by the same letters in columns do not differ according to the Scott-Knott test at $P<0.05$. (A)= net photosynthesis; $(\mathrm{E})=$ transpiration rate.

Table 4. Leaf tissues of Typha domingensis plants grown under different $\mathrm{Cd}$ concentrations. Data is shown as mean \pm standard deviation.

\begin{tabular}{ccccc}
\hline Variable & $\mathbf{0} \boldsymbol{\mu M}$ Cadmium & $\mathbf{1 0} \boldsymbol{\mu M}$ Cadmium & $\mathbf{5 0} \boldsymbol{\mu M}$ Cadmium & $\begin{array}{c}\text { Coefficient of } \\
\text { variation \% }\end{array}$ \\
\hline SDab & $358 \pm 70 \mathrm{a}$ & $352 \pm 91 \mathrm{a}$ & $310 \pm 60 \mathrm{~b}$ & 22.1 \\
$\mathrm{SDad}$ & $324 \pm 64 \mathrm{a}$ & $337 \pm 96 \mathrm{a}$ & $342 \pm 63 \mathrm{a}$ & 22.7 \\
$\mathrm{SIab}$ & $10.21 \pm 1.70 \mathrm{a}$ & $09.29 \pm 2.10 \mathrm{a}$ & $08.83 \pm 1.10 \mathrm{a}$ & 17.9 \\
$\mathrm{SIad}$ & $09.24 \pm 1.30 \mathrm{~b}$ & $10.58 \pm 2.80 \mathrm{a}$ & $09.41 \pm 1.50 \mathrm{~b}$ & 20.9 \\
$\mathrm{EPab}(\mu \mathrm{m})$ & $12.53 \pm 2.50 \mathrm{a}$ & $11.72 \pm 1.80 \mathrm{a}$ & $11.38 \pm 1.10 \mathrm{a}$ & 14.8 \\
$\mathrm{EPad}(\mu \mathrm{m})$ & $11.37 \pm 1.10 \mathrm{a}$ & $12.20 \pm 1.10 \mathrm{a}$ & $10.87 \pm 1.20 \mathrm{a}$ & 9.9 \\
$\mathrm{PPab}(\mu \mathrm{m})$ & $69.96 \pm 21.90 \mathrm{a}$ & $67.50 \pm 29.20 \mathrm{a}$ & $64.24 \pm 23.20 \mathrm{a}$ & 44.3 \\
$\mathrm{PPad}(\mu \mathrm{m})$ & $75.31 \pm 28.20 \mathrm{a}$ & $67.21 \pm 33.80 \mathrm{~b}$ & $60.04 \pm 31.50 \mathrm{~b}$ & 40.0 \\
$\mathrm{AE} \%(\%)$ & $15.07 \pm 8.40 \mathrm{a}$ & $17.17 \pm 6.50 \mathrm{a}$ & $19.51 \pm 5.20 \mathrm{a}$ & 22.4 \\
$\mathrm{VD}(\mu \mathrm{m})$ & $26.02 \pm 6.80 \mathrm{a}$ & $25.07 \pm 5.80 \mathrm{a}$ & $23.19 \pm 4.30 \mathrm{a}$ & 13.9 \\
$\mathrm{VT}(\%)$ & $84.56 \pm 13.60 \mathrm{a}$ & $68.97 \pm 10.20 \mathrm{~b}$ & $66.32 \pm 7.10 \mathrm{~b}$ &
\end{tabular}

Means followed by the same letters in lines do not differ according to the Scott-Knott test at $P<0.05$. (SDab) $=$ abaxial stomatal density; $(\mathrm{SDad})=$ adaxial stomatal density; $(\mathrm{SIab})=$ abaxial stomatal index; $(\mathrm{SIad})=$ adaxial stomatal index; $($ EPab $)=$ abaxial epidermis thickness; $(\mathrm{EPad})=$ adaxial epidermis thickness; $(\mathrm{PPab})=$ abaxial palisade parenchyma thickness; $(\mathrm{PPad})=\mathrm{adaxial}$ palisade parenchyma thickness; $(\mathrm{AE} \%)=$ aerenchymal intercelullar spaces proportion on the leaf area in percentage; $(\mathrm{VD})=\mathrm{xylem}$ vessel diameter; $(\mathrm{VT})=$ Proportion of the vascular tissues (xylem and phloem) in leaf vascular bundles. 


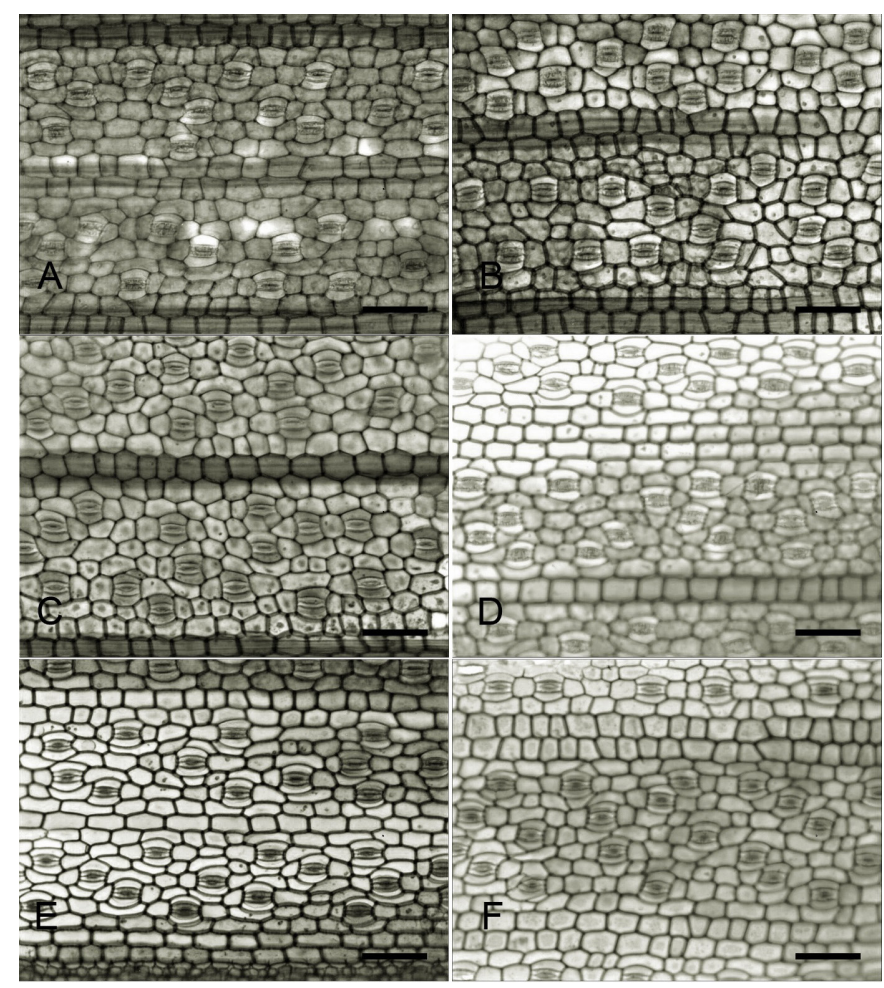

Figure 1. Paradermic sections of Typha domingensis leaves from plants exposed to different $\mathrm{Cd}$ concentrations. A and $\mathrm{B}=0 \mu \mathrm{M}$ of $\mathrm{Cd}\left(\mathrm{NO}_{3}\right)_{2} ; \mathrm{C}$ and $\mathrm{D}=10 \mu \mathrm{M}$ of $\mathrm{Cd}\left(\mathrm{NO}_{3}\right)_{2} ; \mathrm{E}$ and $\mathrm{F}=50 \mu \mathrm{M} \mathrm{Cd}\left(\mathrm{NO}_{3}\right)_{2} . \mathrm{A}, \mathrm{C}$ and $\mathrm{E}=$ Abaxial leaf surface; $\mathrm{B}, \mathrm{D}$ and $\mathrm{F}=$ adaxial leaf surface. bars $=50 \mu \mathrm{m}$.

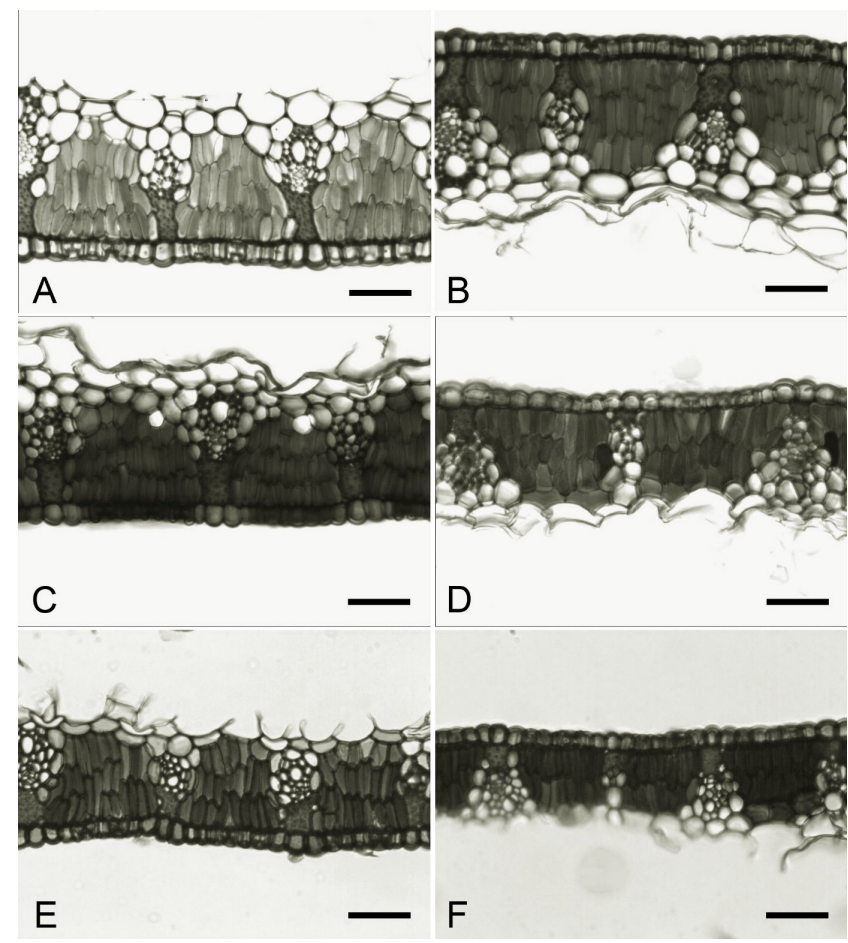

Figure 2. Transversal sections from the adaxial and abaxial sides of the Typha domingensis leaves developed under different Cd concentrations. $\mathrm{A}$ and $\mathrm{B}=0 \mu \mathrm{M} \mathrm{Cd} ; \mathrm{C}$ and $\mathrm{D}=10 \mu \mathrm{M} \mathrm{Cd} ; \mathrm{E}$ and $\mathrm{F}=50 \mu \mathrm{M} \mathrm{Cd} . \mathrm{A}, \mathrm{C}$ and $\mathrm{E}=$ abaxial leaf surface; $\mathrm{B}, \mathrm{D}$ and $\mathrm{F}=$ adaxial leaf surface. bars $=50 \mu \mathrm{m}$. 
A

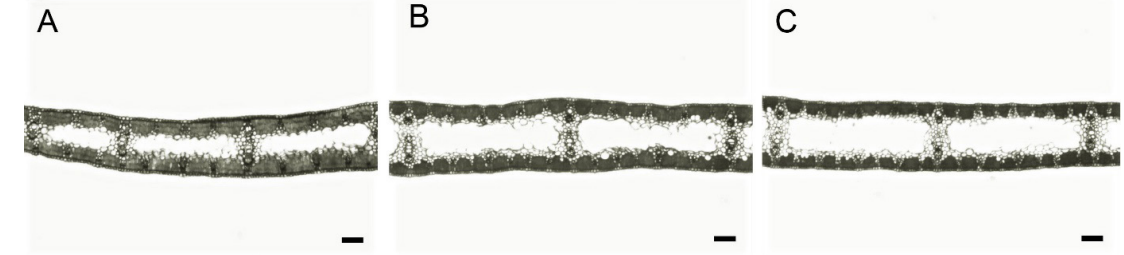

Figure 3. Leaf transversal sections of Typha domingensis plants grown under different Cd concentrations. $\mathrm{A}=0 \mu \mathrm{M} \mathrm{Cd}$; $\mathrm{B}=10 \mu \mathrm{M} \mathrm{Cd} ; \mathrm{C}=50 \mu \mathrm{M} \mathrm{Cd}$. bars $=100 \mu \mathrm{m}$.

\section{Discussion}

The capacity for uptake $\mathrm{Cd}$ of $T$. domingensis shown in the present study is an important trait for its application to phytoremediation systems. The ability to accumulate $\mathrm{Cd}$ is a rare trait found only at five taxa of two plant families (Krämer, 2010). In addition, plants can be considered hyperacumulators when its $\mathrm{Cd}$ concentration on tissues reaches 100 ppm or higher (Krämer, 2010). Therefore, we found that $T$. domingensis can be considered as a $\mathrm{Cd}$-accumulator plant and may be useful in constructed wetland remediation systems. However, our results show that the major part of $\mathrm{Cd}$ was retained in $T$. domingensis roots. Plants that accumulate heavy metal in the root system can be more useful for rhizofiltration systems (Gratão et al., 2005), which is a specific type of phytoremediation method. The heavy metal storage in roots is a common trait in tolerant species (Sharma and Dubey, 2005; Krämer, 2010; Ribeiro et al., 2015). The higher heavy metal content in roots as compared to shoot is related to the root apoplastic barriers which constrain the pollutant transport to shoots protecting the photosynthetic tissues (Ribeiro et al., 2015; Pereira et al., 2017). Therefore, the allocation of $\mathrm{Cd}$ in T. domingensis roots is an important tolerance mechanism which protects the photosynthetic system promoting the maintenance of growth parameters.

Typha domingensis showed several tolerance responses to Cd pollution indicating its potential for use in phytoremediation systems. One of the most important results found here was the capacity to maintain growth by overcoming $\mathrm{Cd}$ toxicity. In fact, $\mathrm{Cd}$ has remarkable effect reducing the growth of non-tolerant plants (Benavides et al., 2005; Gratão et al., 2005). In addition, this metal can constrain the root biomass allocation (Moussa and El-Gamal, 2010) as well as the leaf elongation and shoot biomass (Ye et al., 1997). Hadad et al. (2010) reported that Typha domingensis showed no growth modification under the contamination of $\mathrm{Cr}$, $\mathrm{Ni}$ and $\mathrm{Zn}$.

Another important insight given by the present work is the capacity of $T$. domingensis to maintain growth under $\mathrm{Cd}$ contamination as a result of the photosynthesis stability. In fact, $\mathrm{Cd}$ reduces the photosynthetic activity in several plants (Pietrini et al., 2003), and this reduction can be related to a lower chlorophyll content (Mufarrege et al., 2014). Even tolerant species such as Schinus molle may show lower chlorophyll content under Cd contamination (Pereira et al. 2016). The lower chlorophyll content under
Cd contamination of non-tolerant species is related to the destruction of the chloroplast membranes (Bhaduri and Fulekar, 2012) and the inhibition of the chlorophyll synthesis (Aravind and Prasad, 2004). In addition, significant $\mathrm{Cd}$ toxicity can affect micronutrient transport promoting competition and problems for the metabolism (Asgher et al., 2015). Therefore, the capacity of Typha domingensis to avoid chlorophyll and photosynthesis damage under $\mathrm{Cd}$ contamination is an important tolerance mechanism of this species.

The results for the leaf anatomy of $T$. domingensis under Cd pollution support the photosynthetic and growth responses. Although the palisade parenchyma was reduced by $\mathrm{Cd}$ on the adaxial leaf side, the absence of significant changes on the abaxial side may have balanced the photosynthetic capacity. In tolerant species $\mathrm{Cd}$ has no effect or may increase the leaf and chlorenchyma thickness (Luković et al., 2012; Jia et al., 2015; Pereira et al., 2016). It is known that T. domingensis photosynthetic activity is related to palisade parenchyma thickness (Santos et al., 2015). However, the palisade parenchyma and the stomata on both leaf surfaces of $T$. domingensis may compensate small modifications on just one leaf side. In fact, for amphistomatous leaves, the major limiting factor to photosynthesis is the mesophyll resistance to $\mathrm{CO}_{2}$ diffusion (Terashima et al., 2006). Therefore, leaf modifications to maintain $\mathrm{CO}_{2}$ uptake and diffusion in Typha domingensis may have balanced photosynthesis maintaining growth.

The leaf improved capacity to $\mathrm{CO}_{2}$ uptake and diffusion can be related to the stomata and aerenchyma responses under $\mathrm{Cd}$ contamination. In tolerant species, $\mathrm{Cd}$ can increase the stomatal density which enhances the $\mathrm{CO}_{2}$ uptake and photosynthesis responses (Pereira et al., 2016, 2017). Therefore, the increased stomatal index may have favored $\mathrm{CO}_{2}$ uptake by $T$. domingensis leaves supporting the photosynthetic system. Thus, the stable stomatal traits under $\mathrm{Cd}$ contamination in T. domingensis leaves can be an important tolerance mechanism to maintain photosynthesis under this condition.

In addition to stomatal $\mathrm{CO}_{2}$ uptake, the diffusion of this gas was favored by the aerenchyma development under $\mathrm{Cd}$ contamination. Aerenchyma is related to gas storage and diffusion becoming a key tissue in the plant adaptation to aquatic environments (Insausti et al., 2001; Vasellati et al., 2001; Pereira et al., 2010). In addition, this tissue is also important for the storage of $\mathrm{O}_{2}$ and tissue 
respiration in wetlands (Drew et al., 2000). This tissue was increased by $\mathrm{Cd}$ in the Alternanthera philoxeroides and Polygonum ferrugineu, two aquatic macrophytes (Souza et al. 2009). In addition, Eichhornia crassipes showed higher aerenchyma development under $\mathrm{Cd}$ contamination (Pereira et al., 2017). Therefore, as the percentage of aerenchyma in Typha domingensis leaves were not modified by $\mathrm{Cd}$, the gas diffusion within leaf was preserved and this was important to provide $\mathrm{CO}_{2}$ to palisade parenchyma and maintain photosynthesis. In conclusion, Typha domingensis can overcome $\mathrm{Cd}$ toxicity with tolerance mechanisms resulting in stable growth, photosynthesis and leaf anatomy.

\section{Acknowledgements}

The authors thank CNPq (Conselho Nacional de Desenvolvimento Científico e Tecnológico), and FAPEMIG (Fundação de Amparo à Pesquisa do Estado de Minas Gerais) for funding and research grants awarded to complete the present study.

\section{References}

ARAVIND, P. and PRASAD, M.N.V., 2004. Zinc protects chloroplasts and associated photochemical functions in cadmium exposed Ceratophyllum demersum L., a freshwater macrophyte. Plant Science, vol. 166, no. 5, pp. 1321-1327. http://dx.doi. org/10.1016/j.plantsci.2004.01.011.

ASGHER, M., KHAN, M.I.R., ANJUM, N.A. and KHAN, N.A., 2015. Minimising toxicity of cadmium in plants-role of plant growth regulators. Protoplasma, vol. 252, no. 2, pp. 399-413. PMid:25303855. http://dx.doi.org/10.1007/s00709-014-0710-4.

BENAVIDES, M.P., GALLEGO, S.M. and TOMARO, M.L., 2005. Cadmium toxicity in plants. Brazilian Journal of Plant Physiology, vol. 17, no. 1, pp. 21-34. http://dx.doi.org/10.1590/ S1677-04202005000100003.

BHADURI, A.M. and FULEKAR, M.H., 2012. Antioxidant enzyme responses of plants to heavy metal stress. Environmental Science and Bio/Technology, vol. 11, no. 1, pp. 55-69. http:// dx.doi.org/10.1007/s11157-011-9251-x.

CORREAA, F.F., PEREIRA, M.P., MADAIL, R.H., SANTOS, B.R., BARBOSA, S., CASTRO, E.M. and PEREIRA, F.J., 2016. Anatomical traits related to stress in high density populations of Typha angustifolia L. (Typhaceae). Brazilian Journal of Biology = Revista Brasileira de Biologia. http://dx.doi.org/10.1590/15196984.09715.

DREW, M.C., HE, C.J. and MORGAN, P.W., 2000. Programmed cell death and aerenchyma formation in roots. Trends in Plant Science, vol. 5, no. 3, pp. 123-127. PMid:10707078. http://dx.doi. org/10.1016/S1360-1385(00)01570-3.

FERREIRA, D.F., 2011. Sisvar: a computer statistical analysis system. Ciência e Agrotecnologia, vol. 35, no. 6, pp. 1039-1042. http://dx.doi.org/10.1590/S1413-70542011000600001.

GONÇALVES, V.C., MEURER, E.J., TATSCH, F.R.P., CARVALHO, S.A. and SANTOS NETO, O.A., 2008. Biodisponibilidade de cádmio em fertilizantes fosfatados. Revista Brasileira de Ciência do Solo, vol. 32, no. spe, pp. 2871-2875. http://dx.doi.org/10.1590/ S0100-06832008000700034.

GRATÃO, P.L., PRASAD, M.N.V., CARDOSO, P.F., LEA, P.J. and AZEVEDO, R.A., 2005. Phytoremediation: green technology for the clean up of toxic metals in environment. Brazilian Journal of Plant Physiology, vol. 17, no. 1, pp. 53-64. http://dx.doi. org/10.1590/S1677-04202005000100005.

HADAD, H.R., MUFARREGE, M.M., PINCIROLI, M., DI LUCA, G.A. and MAINE, M.A., 2010. Morphological response of Typha domingensis to an industrial effluent containing heavy metal in a constructed wetland. Archives of Environmental Contamination and Toxicology, vol. 58, no. 3, pp. 666-675. PMid:20041323. http://dx.doi.org/10.1007/s00244-009-9454-0.

HEGAZY, A.K., ABDEL-GHANI, N.T. and EL-CHAGHABY, G.A., 2011. Phytoremediation of industrial wastewater potentiality by Typha domingensis. International Journal of Environmental Science and Technology, vol. 8, no. 3, pp. 639-649. http://dx.doi. org/10.1007/BF03326249.

HOAGLAND, D.R. and ARNON, D.I., 1950. The water-culture method for growing plants without soil. Davis: California Agricultural Experiment Station.

INSAUSTI, P., GRIMOLDI, A.A., CHANETON, E.J. and VASELLATI, V., 2001. Flooding induces a suite of adaptive plastic responses in the grass. Paspalum dilatatum. The New Phytologist, vol. 152, no. 2, pp. 291-299. http://dx.doi.org/10.1111/j.0028646X.2001.257_1.X.

JIA, L., LIU, Z., CHEN, W., YE, Y., YU, S. and HE, X., 2015. Hormesis effects induced by cadmium on growth and photosynthetic performance in a hyperaccumulator, Lonicera japonica Thunb. Journal of Plant Growth Regulation, vol. 34, no. 1, pp. 13-21. http://dx.doi.org/10.1007/s00344-014-9433-1.

JOHANSEN, D.A., 1940. Plant microtechnique. London: McGraw-Hill Book Company, Inc. 523 p.

KRÄMER, U., 2010. Metal hyperaccumulation in plants. Annual Review of Plant Biology, vol. 61, no. 1, pp. 517-534. PMid:20192749. http://dx.doi.org/10.1146/annurev-arplant-042809-112156.

KRAUS, J.E. and ARDUIN, M., 1997. Manual básico de métodos em morfologia vegetal. Seropédica: EDUR. 198 p.

LOMINCHAR, M.A., SIERRA, M.J. and MILLÁN, R., 2015. Accumulation of mercury in Typha domingensis under field conditions. Chemosphere, vol. 119, pp. 994-999. PMid:25303659. http://dx.doi.org/10.1016/j.chemosphere.2014.08.085.

LUKOVIĆ, J., MERKULOV, L., PAJEVIĆ, S., ZORIĆ, L., NIKOLIĆ, N., BORIŠEV, M. and KARANOVIĆ, D., 2012. Quantitative assessment of effects of cádmium on the histological structure of poplar and willow leaves. Water, Air, and Soil Pollution, vol. 223, no. 6, pp. 2979-2993. http://dx.doi.org/10.1007/s11270012-1081-0.

MOUSSA, H.R. and EL-GAMAL, S.M., 2010. Effect of salicylic acid pretreatment on cadmium toxicity in wheat. Biologia Plantarum, vol. 54, no. 2, pp. 315-320. http://dx.doi.org/10.1007/ s10535-010-0054-7.

MUFARREGE, M.M., HADAD, H.R., DI LUCA, G.A. and MAINE, M.A., 2014. Metal dynamics and tolerance of Typha domingensis exposed to high concentrations of $\mathrm{Cr}, \mathrm{Ni}$ and $\mathrm{Zn}$. Ecotoxicology and Environmental Safety, vol. 105, pp. 90-96. PMid:24793518. http://dx.doi.org/10.1016/j.ecoenv.2014.04.008. 
MUFARREGE, M.M., HADAD, H.R., DI LUCA, G.A. and MAINE, M.A., 2015. The ability of Typha domingensis to accumulate and tolerate high concentrations of $\mathrm{Cr}, \mathrm{Ni}$, and $\mathrm{Zn}$. Environmental Science and Pollution Research International, vol. 22, no. 1, pp. 286-292. PMid:25062549. http://dx.doi.org/10.1007/ s11356-014-3352-3.

PEREIRA, F.J., CASTRO, E.M., OLIVEIRA, C., PIRES, M.F. and PASQUAL, M., 2011. Anatomical and physiological mechanisms of water hyacinth plants to arsenic contamination tolerance. Planta Daninha, vol. 29, no. 2, pp. 259-267. http://dx.doi.org/10.1590/ S0100-83582011000200003.

PEREIRA, F.J., CASTRO, E.M., OLIVEIRA, C., PIRES, M.F., PEREIRA, M.P., RAMOS, S.J. and FAQUIN, V., 2014. Lead tolerance of water hyacinth (Eichhornia crassipes Mart. - Pontederiaceae) as defined by anatomical and physiological traits. Anais da Academia Brasileira de Ciencias, vol. 86, no. 3, pp. 1423-1433. PMid:25211112. http://dx.doi.org/10.1590/00013765201420140079 .

PEREIRA, F.J., CASTRO, E.M., PIRES, M.F., OLIVEIRA, C. and PASQUAL, M., 2017. n press. Anatomical and physiological modifications in water hyacinth under cadmium contamination. Journal of Applied Botany and Food Quality

PEREIRA, F.J., MAGALHÃES, P.C., SOUZA, T.C., CASTRO, E.M. and ALVES, J.D., 2010. Atividade do sistema antioxidante e desenvolvimento de aerênquima em raízes de milho 'Saracura'. Pesquisa Agropecuária Brasileira, vol. 45, no. 5, pp. 450-456. http://dx.doi.org/10.1590/S0100-204X2010000500003.

PEREIRA, M.P., RODRIGUES, L.C.A., CORRÊA, F.F., CASTRO, E.M., RIBEIRO, V.E. and PEREIRA, F.J., 2016. Cadmium tolerance in Schinus molle trees is modulated by enhanced leaf anatomy and photosynthesis. Trees, vol. 30, no. 3, pp. 807-814. http://dx.doi.org/10.1007/s00468-015-1322-0.

PERKOVICH, B.S., ANDERSON, T.A., KRUGER, E.L. and COATS, J.R., 1996. Enhanced mineralization of [14C] atrazine in Kochia scoparia Rhizosferic soil from a pesticide-contaminated site. Pesticide Science, vol. 46, no. 4, pp. 391-396. http:// dx.doi.org/10.1002/(SICI)1096-9063(199604)46:4<391::AIDPS374>3.0.CO;2-L.
PIETRINI, F., IANNELLI, M.A., PASQUALINI, S. and MASSACCI, A., 2003. Interaction of cadmium with glutathione and photosynthesis in developing leaves and chloroplasts of Phragmites australis (Cav.) Trin. ex Steudel. Plant Physiology, vol. 133, no. 2, pp. 829-837. http://dx.doi.org/10.1104/pp.103.026518.

RIBEIRO, E.S., PEREIRA, M.P., CASTRO, E.M., BARONI, G.R., CORRÊA, F.F. and PEREIRA, F.J., 2015. Relações da anatomia radicular na absorção, no acúmulo e na tolerância ao chumbo em Echinodorus grandiflorus. Revista Brasileira de Engenharia Agrícola e Ambiental, vol. 19, no. 6, pp. 605-612. http://dx.doi.org/10.1590/1807-1929/agriambi.v19n6p605-612.

SANTOS, K.R., PEREIRA, M.P., FERREIRA,A.C.G., RODRIGUES, L.C.A., CASTRO, E.M., CORRÊA, F.F. and PEREIRA, F.J., 2015. Typha domingensis Pers. Growth responses to leaf anatomy and photosynthesis as influenced by phosphorus. Aquatic Botany, vol. 122, pp. 47-53. http://dx.doi.org/10.1016/j.aquabot.2015.01.007.

SHARMA, P. and DUBEY, R.S., 2005. Lead toxicity in plants. Brazilian Journal of Plant Physiology, vol. 17, no. 1, pp. 35-52. http://dx.doi.org/10.1590/S1677-04202005000100004.

SOUZA, V.L., SILVA, D.D.C., SANTANA, K.B., MIELKE, M.S., ALMEIDA, A.F., MANGABEIRA, P.A.O. and ROCHA, E.A., 2009. Efeitos do cádmio na anatomia e na fotossíntese de duas macrófitas aquáticas. Acta Botanica Brasílica, vol. 23, no. 2, pp. 343-354. http://dx.doi.org/10.1590/S0102-33062009000200006.

TERASHIMA, I., HANBA, Y.T., TAZOE, Y., VYAS, P. and YANO, S., 2006. Irradiance and phenotype: comparative eco-development of sun and shade leaves in relation to photosynthetic $\mathrm{CO}_{2}$ diffusion. Journal of Experimental Botany: Oxford Journals, vol. 57, no. 2, pp. 343-354. PMid:16356943. http://dx.doi.org/10.1093/jxb/erj014.

VASELLATI, V., OESTERHELD, M., MEDAN, D. and LORETI, J., 2001. Effects of flooding and drought on the anatomy of Paspalum dilatatum. Annals of Botany, vol. 88, no. 3, pp. 355360. http://dx.doi.org/10.1006/anbo.2001.1469.

WELZ, B. and SPERLING, M., 2008. Atomic absorption spectrometry. Weinheim: Wiley-VCH. 965 p.

YE, Z.H., BAKER, J.M., WONG, M.H. and WILLIS, A.J., 1997. Zinc, lead and cadmium tolerance, uptake and accumulation by Typha latifolia. The New Phytologist, vol. 136, no. 3, pp. 469-480. http://dx.doi.org/10.1046/j.1469-8137.1997.00759.x. 